Saudi Journal of Business and Management Studies Abbreviated Key Title: Saudi J Bus Manag Stud ISSN 2415-6663 (Print) |ISSN 2415-6671 (Online) Scholars Middle East Publishers, Dubai, United Arab Emirates Journal homepage: http://scholarsmepub.com/sjbms/

Original Research Article

\title{
Impact of Information and Communication Technology Innovation on Service Quality in Kaduna State, Nigeria
}

\author{
Iluno Ezinne Chinyere, Charles J. Mambula I Ph.D*
}

Associate Professor/Chair, Department of Entrepreneurial Studies/ Director Center of Entrepreneurial Studies \& Research, Langston University School of Business, 701 Sammy Davis Jr Dr, Langston, OK 73050, USA

\author{
DOI:10.36348/sjbms.2019.v04i09.010 \\ | Received: 05.09.2019 | Accepted: 13.09.2019 | Published: 30.09.2019
}

*Corresponding author: Charles J. Mambula I

\section{Abstract}

The survival of banking industry is tied to their ability to use information and communication technology facilities to enhance their operational efficiency. Thus, banks are expected to strategically improve on the quality of services provided to their customers in order to remain relevant in a competitive environment. This paper assesses the impact of ICT innovation on service quality. The study made use of both primary and secondary data instruments for data gathering, questionnaires were used for gathering primary data and data from internet, journal were means of secondary data collection. Four hundred (400) banks' customers were served with questionnaire, out of which only 360 were returned. SPSS version 20 and Regression were used in testing the hypothesis. The result revealed that ICT innovation has a positive impact on Assurance, responsiveness and tangibility, while it has a negative impact on empathy and reliability. It is recommended that banks should ensure that all staff are trained to be more innovative to be able to deliver superior services.

Keywords: Information Communication Technology Innovation, Service Quality, Customer Satisfaction.

Copyright @ 2019: This is an open-access article distributed under the terms of the Creative Commons Attribution license which permits unrestricted use, distribution, and reproduction in any medium for non-commercial use (NonCommercial, or CC-BY-NC) provided the original author and source are credited.

\section{INTRODUCTION}

The survival and growth of any organization is a function of their responsiveness to customer's demand. It is widely acclaimed that customers are the main focus and reason for the establishment of any business entity. This has resulted in an increasing pressure to outsmart others in the bid to win customers' and retain them. The banking industry in Nigeria is an important sector as it contributes significantly to the economic growth of the country. The need to reform and reposition the bank to a sound entity like it other counterparts in the globe has mandated the bank to look for ways to harness the opportunity made available by Information and Communication Technology (ICT). The ICT has become very significance in the world, as it changes virtually all aspect of human life. There is no one acceptable definition of ICT, however, it consist of all devices that enables people and institution to interact digitally. One of the significant way the banking industry has employ the services of information technology is the use of electronic banking (EBanking). E-Banking has open up banking industry to better ways of delivering banking product and services both locally and internationally. It has also reduce drastically some of the loopholes witnessed during the brick and mortar banking.

The advent of ICT has added value to the banking operations because it has significantly changed the conventional banking habit to a more efficient and effective E-banking. E-banking is one of the product or service of ICT which place the customers in charge of their operations. Banks knowing the role of ICT as a prerequisite for global competition has invested heavily 
to reposition itself because the growth and survival of any firm is tied to how far they can produce quality goods and services to their esteemed customers. Thus, effective and satisfactory services enhance the value of a firm, thereby boosting its revenue. E-banking services has become practice among deposit money banks in Nigeria because of its benefit of time saving, speed and convenience among others. It has also played an important role in the economy by enhancing government cashless policy. The choice of customers are largely influenced by the degree of innovation the bank has attained.

Service quality remain one of the strategic tool employed by organization to compete favorably among community of nations. It is the ability of a product or service to meet the expectations of the customer against their perception. Service quality has been recognized as a tool that must be harnessed to keep customers expectant. Customer's satisfaction is a measure of how banks have translated their strategy (service quality) to deliver valuable product and service that gives customers reason to continue operating with the bank.

Banking industry is evolving into a highly competitive and technological innovative as they were previously faced with challenges of illiquidity, poor service delivery, fraud, long queue and lack of professionalism which lead to dissatisfaction on the part of their customers. The manual operational method of banking is marred by inefficiency and this has led to time wastage from initiation to the completion of bank transactions. This is more obvious when the transaction involves cross country reconciliation. Most banks in Nigeria have over the years changed their banking operations from analogue to digital system of banking to capture the financial market. The banking industry is now characterized by developing their business models, customer sophistication, technology, regulation and supervision [1]. The adoption of ICT in banking system began in year 1999 because of the commitment of the Federal Government (FG) to develop a national ICT infrastructure [2].

The ICT Development Index (IDI) revealed that investment on ICT have risen from $\$ 50 \mathrm{~m}$ to $\$ 32 \mathrm{~b}$ between the periods 1999 to 2014 [3]. This investment by both government and private sectors on ICT has grown over the years and yet more are needed to be done to match the investment on ICT infrastructure and satisfaction derive by customers. This huge investment on ICT have not translated to customer satisfaction, this is because not much investment has be done on the training and retraining of the bank personnel and customers that utilize this technologies.

There are several literatures on electronic banking services and customers' satisfactions especially those of [4-9] argued that e-banking services have significant and positive impact on customers' satisfactions. Furthermore, they are of the opinion that the introduction of ICT has improved customer satisfaction. On the other hand [10-13] have a contrary opinion as they found that electronic banking has not improved customer satisfaction.

Despite several studies on the impact of Ebanking and customer satisfaction worldwide, there is no study on the impact of ICT innovation on service quality conducted in Kaduna State. For the purpose of this study E-Banking is proxy by ICT innovation, while Customer satisfaction is proxy by service quality.

It is against this background, that the study examines the impact of ICT innovation and service quality on customer's satisfaction in Kaduna State. In order to achieve this objective, the study proposes the following statement of null hypothesis:

$\mathrm{Ho}_{1}$ : ICT Innovation does not have any significant impact on Responsiveness.

$\mathrm{Ho}_{2}$ : ICT Innovation does not have any significant impact on Empathy.

$\mathrm{Ho}_{3}$ : ICT Innovation does not have any significant impact on Tangibility.

$\mathrm{Ho}_{4}$ : ICT Innovation does not have any significant impact on Assurance.

$\mathrm{Ho}_{5}$ : ICT Innovation does not have any significant impact on Reliability.

To this end, the paper is organized as follows, following the introduction, section two gives a brief review of the literature while the methodology of the study is presented in section three. Also, section four presents data analyses and interpretation of results while the last section is for summary, conclusion and recommendation.

\section{LITERATURE REVIEW ICT Innovation}

ICT innovation has gradually changed the way banks formally present their products and services, it provides more personalized and convenient way of banking anytime without the restriction of any sort. Innovation is significant to maintain a strategic edge in the banking sectors, as it changes rapidly as human need emerge. Customers are not only interested in the safety of their fund but also on some additional value attached to the product. This technological innovation transformed the Nigerian financial landscape to an advantageous one, because of the numerous benefits. Banks globally have shifted from analogue system of rendering services to electronic medium. Customers taste keeps changing as they are willing to get extra personalized product and service which make life better for them. There are different ICT innovations adopted by banks, for the purpose of this study the focus is on few commonly used ones like Automated Teller Machine (ATM), Mobile banking (MB), Online banking (OLB), and Point of Sale (POS). 
ATM is a device that allows a customer to withdraw cash from his account via cash dispenser (machine) and his account debited immediately. They are mostly located outside the bank and also in strategic places like offices, airport, hotel where people can easily have access. ATM offer range of services but most ATM's in Nigeria do not allow for deposit as obtained in developed economy.

POS is an electronic device that is used in verifying and processing credit card transaction. A retail POS system include computer, monitor, cash drawer, receipt printer, customer display and a barcode scanner. Most retail outlet use it to reduce the rate at which they handle cash and also the difficulty encounter in getting change for customers do not arise when using POS.

MB is defined by Worku, Tiluhun and Tafa [14] as a device used to perform balance checks, account transactions, payments, credit application and other banking transaction through a mobile device such as a mobile phone or personal digital assistant. MB provides convenience for customers because it occur at the convenience of their comfort

OLB is a term used for performing banking transaction via internet and computer. It gives accessibility to perform banking operation from any location and these has change the landscape of how banking is carried out in Nigeria [15].

\section{Concept of Service Quality}

The attribute of a good firm is dependent on the service quality rendered to their customer. Service quality is the potential to deliver strategic benefits such loyalty, efficiency and higher revenue. Service quality and customer satisfaction are two important concepts in the banking industry, because the end product of quality service is satisfaction or dissatisfaction since every effort and strategy put forward by the firm from the production to consumption is solely for that purpose. The quality of services is always seem from the customer's side, because the customer will weigh his/her perception before and after usage. Jahanshani, Hajizadeh, Mirdhamadi, Nawaser and Khakar [16] opined that customer satisfaction is a response (emotional or cognitive) that pertains to a particular focus (expectation, product, consumption experience, and so on) and occurs at a particular time (after consumption, after choice, based on accumulated experience, and so on). If banks must improve and make profit, it must always understand and strategize to deliver high quality service to its customer and ready to continually review the strategy as their need changes. Peyton, Pitts, and Kamery [17] and Erjavec [18] indicated that other variables like loyalty and retention can be used to study measure satisfaction.

Customer satisfaction depends on the dimension of service quality (Servqual) which was created by Berry, Parasuraman and Zeithaml 1988 [15]. It has two components namely customer perception and customer expectation and also identifies five criteria

- Tangibles: They are the physical or visual facilities like staff, equipment, surroundings and material. It is use to show the richness and image of professional quality and standard [19]

- Reliability: The ability of a firm to be accurate in dealings with customers

- Assurance: It is a combination of courtesy, trustworthiness, competence and security

- Empathy: It is the ability to understand the customers and their individual needs. It is giving personalize attention to services even in uncomfortable condition to serve the customer better.

- Responsiveness: Provision of prompt services as at when needed

\section{ICT Innovation and Customer Satisfaction}

Banks invest in technology to increase efficiency, minimize cost, increase revenue and retain customers amongst others. Banks use ICT to enhance their efficiency of services offered to customers and strategically position itself to compete globally. ICT innovation change rapidly as customers taste changes and as the need arises. The banks at all-time keep abreast of the changing scenario, since it been proactive helps in retaining their customers and in the long run result to increase market share. ICT is a key element as it affects all processes of human existence. Banks must make ICT innovation appealing to customers in a personalized form and this can be done through ICT advertisement and awareness.

\section{Theoretical Issues}

There are various theories that explains ICT innovation on service quality. Among these theories are innovation diffusion theory (IDT) and Technology Acceptance Model (TAM).

\section{Innovation Diffusion Theory (IDT)}

Innovation Diffusion Theory (IDT) is a theory propounded by Everett Rogers in 1983. This theory has shown that technological innovation is communicated through a particular channel over time among the members of a social system. From the concept of innovation diffusion, customers and organizations adopts technology to perform activities that are advantageous. The five stages (steps) of this theory are: awareness, interest evolution, trial and adoption Therefore, most banks have adopted ICT to improve their efficiency and service delivery. This technology is achieved through the development of website and mobile application that suits the customer's needs. This enables customers to assess their account anywhere as far as they are connected to the internet. Rogers was convinced that the adoption of innovation follows a universal process of social change. Some studies that have adopted IDT [20, 21]. 


\section{Technology Acceptance Model (TAM)}

Technology Acceptance Model (TAM) was develop by Davis in 1985, it is an information systems theory that shows how users accept and use technology. TAM has been widely accepted as a valid model in individual acceptance behavior across various information technologies and their users [22].

This study is anchored on IDT. This is because the IDT explains the motive behind the adoption of ICT by financial institutions such deposit money banks, which is geared towards enhancement of operational efficiency and thus improve customer satisfaction.

\section{Empirical Review}

Gontur, Hassan and Arin [22] assessed the role of information Technology in building customer loyalty in money deposit banks in Jos Metropolis. The study adopted questionnaire to generate data from the respondents. Data was analyzed using statistical technique like Pearson product moment correlation coefficient and linear regression. The result revealed that there is a significant relationship between the use of ATM and customer loyalty and there is a significant relationship between mobile banking, internet banking and customer loyalty. However, the study focused on the role of information technology in building customer loyalty in Jos metropolis, but not in Kaduna State.

Odusina and Onakoya [23] studied the relationship between electronic payment system and customer retention in banks for entrepreneurial development in Nigeria using the instrument of questionnaire for data collection. Multiple regression using SPSS was used for data analysis. The result showed positive and significant relationship between electronic payment system and customer retention. However, the study only concentrated on electronic system and customer retention with nothing done on customer satisfaction and service quality. Furthermore, the use of only the instrument is not sufficient for a study of this scope.

Agada and Meysam [2] examined the impact of information and communication technology service quality on customer satisfaction in Nigeria banking sector. Convenience sampling technique was used to collect quantitative data. Each servqual dimension was used to test the significant relationship it has on customer satisfaction. The finding revealed that ICT innovation improve service quality.

Ameme and Wireko [24] studied customer satisfaction and the associated cost of electronic banking services with specific reference to banking customers in Ghana. The sample size was fifty. Data was collected through the instrument of questionnaire, Cronbach's alpha and chi-square were used to analyze the data. The findings showed that the cost associated with technological innovation in the banking have also increased transactions costs to the disadvantages of customers. However, the choice of 10 respondents from each of the five branches of the bank is too small and have affected the outcome of the study. Hence the sample size of 50 is too small Furthermore, the methodology seems to be weak as only the instrument of questionnaire was used for data collection

Taiwo [25] assessed the impact of information technology on accounting system and organizational performance. The study utilizes secondary data and Pearson's correlation for data analysis using SPSS for a sample of 20 staff in financial services and other related accounting department in Covenant University. The result revealed that there is a significant positive relationship between ICT system and accounting system and a significant positive relationship between ICT and organizational performance. However, the study only investigated accounting system and organizational performance not service quality. More so, the methodology seems weak as instrument of secondary data was used. Thus, this has created a vacuum in the contextual literature.

Ilo, Ani and Chioke [26] studied the impact of technological innovation on delivery of banking services in Nigeria using the instrument of questionnaire for data collection. The data analysis involved frequency distribution and the use of Pearson correlation statistics that were adopted in Statistical Package for Social Sciences (SPSS). The findings showed that a positive relationship exist between technology innovation and bank employee's performance. It also showed that the introduction of ICT improves customer satisfaction and retention and there is a significant relationship between technology innovation and service delivery. However, the study methodology seems to be weak by using only the instrument of questionnaire. Thus, this has created a vacuum in the contextual literature.

Alabar and Agema [27] used empirical approach to determine the relationship that exist between the current state of ICT and customer satisfaction in Nigeria banking industry. The study used the instrument of questionnaire for data collection and regression analysis for data analysis. The result revealed that the present state of ICT had significant influence on customer satisfaction. Through the sample size of 400 respondents was large enough, the use of only questionnaire as an instrument of data collection make the only focus on ICT and customer satisfaction with little or nothing done on service quality

Ankrah [28] assessed technology and service quality in the banking industry in Ghana. The study used the instrument of questionnaire for primary data collection and internet, organization's website, board minutes and brochures for secondary data collection. Data were analyzed using chi-square. The finding 
revealed that personalization Service quality, price. Ease of use, access and availability, security and technology have positive impact on customer satisfaction. However, the methodology seems to be weak as the use of chi-square for a study of this scope is not sufficient to give a better result.

\section{METHODOLOGY}

Primary data was sourced via questionnaire instrument on the impact of ICT innovation on customers' satisfaction in Kaduna State, Nigeria. The Data was analyzed using SPSS and regression analysis.

The population of this study is $1,085,994$ respondents who represent customers that are of eligible age for holding a bank account and are financially inclusive in [29]. The sample size of 400 respondents from the three senatorial districts of Kaduna State was chosen. The Local Government Areas chosen from there distribution are: Zaria, Lere, Sabon-Gari, Igabi, Kaduna South, Kaduna North, Zango, Jema'a and Kachia. The choice of the local governments were based on the heavy economic activities, population density, as well as perceived high concentration of Ebanking services. The sample size of this study was determine through Yamane 1964 [30].

$$
\mathrm{S}=\frac{N}{1+N\left(M E^{2}\right)}
$$

Where: $\mathrm{S}$ is the desired sample; ' $N$ ' is the population size; and ' $M E$ ' is the margin of error allowed to determine the sample size:

$$
S=\frac{1,085994}{1+1,085994(0.05)^{2}}=400
$$
follows.

The determination of the number of respondents for each of the sample LGCs was done proportionately as

$$
\text { No of Respondents }=\frac{\text { population of each LGC }}{\text { Total Pop.of the } 9 \text { sample LGC }} \times \text { sample size }
$$

A 20- item questions were designed to get the views of how customer's expectations are met with ICT innovation.

\section{Model Specification}

In order to assess the impact of ICT innovation on customer satisfaction in Kaduna State, Nigeria, the study mathematical model is specified as follows;

Servqual=f (Assurance, Empathy, Responsive, Reliability, Tangibility)

Equation can be rewritten in stochastic format thus

ICT INNV $=b_{0}+b_{1} R E L+b_{2}$ TAN $+b_{3} A S S+b_{4}+$ $\mathrm{RESP}+\mathrm{b}_{5} \mathrm{EMP}+\mathrm{U}$

Where,

ICT $=$ comprises of ATM, POS, Electronic banking, debit and credit cards, and all technological devices used in the bank. $\mathrm{b}_{\mathrm{o}}=$ Intercepts

$b_{1}-b_{5}=$ are the coefficients of the estimated parameters

$\mathrm{U}=$ Error term.

REL $=$ Reliability

TAN= Tangibility

ASS $=$ Assurance

RES $=$ Responsiveness

$\mathrm{EMP}=$ Empathy

\section{RESULTS AND DISCUSSION}

This section presents the result of data analysis and test of hypothesis formulated in the introductory section of the paper. Thus, the data were analyzed through descriptive statistics and the results of the regression are thereafter presented for discussion.

\section{Test of Hypotheses:}

H0 $0_{1}$ ICT Innovation does not have any significant impact on Tangibility.

Table-1: Respondents views on ICT Innovation on Tangibility

\begin{tabular}{|c|c|c|c|c|}
\hline Options & Respondents & Percent & Ranking & Weighted mean Ave mean \\
\hline Strongly Agreed & 262 & 72.78 & 5 & 1310 \\
\hline Agreed & 66 & 18.33 & 4 & 264 \\
\hline Neutral & 14 & 3.89 & 3 & 42 \\
\hline Disagreed & 10 & 2.78 & 2 & 20 \\
\hline Strongly Disagreed & 08 & 2.22 & 1 & 08 \\
\hline Total & 360 & 100.00 & 1644 & $1644 / 360=4.6$ \\
\hline
\end{tabular}

Source: Researchers computation, using SPSS version 20 software, 2019

From Table-1, $91.11 \%$ of the respondents are of the view that tangibility nature of ICT innovation contributes to customers' satisfaction significantly. Tangibility are those physical features such as the building, neatness of staff that appeal to the customer. Likewise, $5 \%$ of the respondents stated that the physical state of the ICT innovation did not impact on customers' satisfaction, for instance the location and the 
Iluno Ezinne Chinyere \& Charles J. Mambula I; Saudi J Bus Manag Stud, Sep 2019; 4(9): 765-773

physical features of the ATM. Subsequently, the weighted average mean score of the respondent on five likert scale is $4.6>3.0$ criterion value. This implies that in general, most of the respondent agrees that tangible nature of ICT products are appealing.

\section{$\mathrm{Ho}_{2}$ : ICT Innovation does not have any significant impact on Responsiveness.}

Table-2: Respondents views on ICT Innovation on Responsiveness

\begin{tabular}{|c|c|c|c|c|}
\hline Options & Respondents & Percent & Ranking & Weighted mean Ave mean \\
\hline Strongly Agreed & 85 & 23.61 & 5 & 425 \\
\hline Agreed & 105 & 29.17 & 4 & 420 \\
\hline Neutral & 47 & 13.06 & 3 & 141 \\
\hline Disagreed & 65 & 18.06 & 2 & 130 \\
\hline Strongly Disagreed & 58 & 16.11 & 1 & 58 \\
\hline Total & 360 & 100.00 & 1174 & $1174 / 360=3.3$ \\
\hline
\end{tabular}

Source: Researchers computation, using SPSS version 20 software, 2019

From the result, about $53 \%$ of the respondents are of the view that bank respond swiftly to customer need and complaint, while $13 \%$ are neutral about bank's response to their desires. Likewise, $34 \%$ of the respondents are of the opinion that bank staff do not respond to the problems of their customers as at when due. For instance, the seizure of electronic card and debit without payment are not mostly treated with the urgency that it required. Subsequently, the weighted average mean score of the respondent on five likert scales is $3.3>3.0$ criterion value. This implies that most of the respondent are of the opinion that bank respond promptly.

\section{$\mathrm{H0}_{3}$ : ICT Innovation does not have any significant impact on Assurance}

Table-3: Respondents views on ICT Innovation on Assurance

\begin{tabular}{|c|c|c|c|c|}
\hline Options & Respondents & Percent & Ranking & Weighted mean Ave mean \\
\hline Strongly Agreed & 56 & 15.56 & 5 & 280 \\
\hline Agreed & 175 & 48.61 & 4 & 700 \\
\hline Neutral & 38 & 10.56 & 3 & 114 \\
\hline Disagreed & 43 & 11.94 & 2 & 86 \\
\hline Strongly Disagreed & 48 & 13.33 & 1 & 48 \\
\hline Total & 360 & 100.00 & 1228 & $11228 / 360=3.4$ \\
\hline
\end{tabular}

Source: Researchers computation, using SPSS version 20 software, 2019

From the result, $64 \%$ of the respondents are of the view that bank are credible and understand their needs and also treat them with respect that they deserve. Likewise, $25 \%$ of the respondents are of the opinion that bank staff do not respond to the problems of their customers as at when due. For instance the seizure of ATM card and debit without payment are not mostly treated with the urgency that it required. Subsequently, the weighted average mean score of the respondent on five likert scales is $3.4>3.0$ criterion value. This implies that in general, most of the respondent are of the opinion that bank staff do know their responsibility and inspire confidence in customers.

\section{H0 $_{4}$ : ICT Innovation does not have any significant impact on Empathy.}

Table-4: Respondents views on ICT Innovation on Empathy

\begin{tabular}{|c|c|c|c|c|}
\hline Options & Respondents & Percent & Ranking & Weighted mean Ave mean \\
\hline Strongly Agreed & 67 & 18.61 & 5 & 335 \\
\hline Agreed & 160 & 44.44 & 4 & 640 \\
\hline Neutral & 27 & 07.50 & 3 & 81 \\
\hline Disagreed & 73 & 20.28 & 2 & 146 \\
\hline Strongly Disagreed & 33 & 09.17 & 1 & 33 \\
\hline Total & 360 & 100.00 & 1235 & $1235 / 360=3.4$ \\
\hline
\end{tabular}

Source: Researchers computation, using SPSS version 20 software, 2019

From the result, $63 \%$ of the respondents are of the view that bank are sympathetic about their personal needs and complaint. Likewise, $29 \%$ of the respondents are of the opinion that bank staff do not consider customers feelings and do not put themselves in the customer place. For instance, it takes time for customers account to be credited when transaction was not successfully executed, especially when transaction is carried out in another bank. Subsequently, the weighted average mean score of the respondents on the five likert 
Iluno Ezinne Chinyere \& Charles J. Mambula I; Saudi J Bus Manag Stud, Sep 2019; 4(9): 765-773

scales is $3.4>3.0$ criterion value. This implies that most out of their comfort to meet their needs.

of the respondents are of the opinion that bank staff go

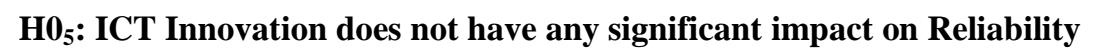

Table-5: Respondents views on ICT Innovation on Reliability

\begin{tabular}{|c|c|c|c|c|}
\hline Options & Respondents & Percent & Ranking & Weighted mean Ave mean \\
\hline Strongly Agreed & 65 & 18.06 & 5 & 325 \\
\hline Agreed & 34 & 09.40 & 4 & 136 \\
\hline Neutral & 42 & 11.67 & 3 & 126 \\
\hline Disagreed & 174 & 48.33 & 2 & 348 \\
\hline Strongly Disagreed & 45 & 12.50 & 1 & 45 \\
\hline Total & 360 & 100.00 & 980 & $980 / 360=2.7$ \\
\hline
\end{tabular}

Source: Researchers computation, using SPSS version 20 software, 2019

From the result, $27 \%$ of the respondents believe that banks keep to their words. Likewise, $60.83 \%$ of the respondents are of the opinion that bank staff are not to be relied upon because they do not keep to their promise. This could be attributed to lack of fund or other problems encounter in using some ICT product.
Subsequently, the weighted average mean score of the respondent on five likert scales is $2.7<3.0$ criterion value. This implies that in general, most of the respondent do not rely on banks to accurately perform their services.

Table-6:

\begin{tabular}{|c|c|c|c|c|}
\hline \multicolumn{5}{|c|}{ Dependent Variable: ICT Innovation } \\
\hline \multicolumn{5}{|l|}{ Method: Least Squares } \\
\hline \multicolumn{5}{|c|}{ Date: 06/06/19 Time: 13:37 } \\
\hline \multicolumn{5}{|l|}{ Sample: 1360} \\
\hline \multicolumn{5}{|c|}{ Included observations: 360} \\
\hline Variable & Coefficient & Std. Error & t-Statistic & Prob. \\
\hline $\mathrm{C}$ & -0.495937 & 0.063441 & -7.817277 & 0.0000 \\
\hline ASS & 0.313837 & 0.031876 & 9.845713 & 0.0000 \\
\hline EMP & -0.225517 & 0.035310 & -6.386867 & 0.0000 \\
\hline REL & -0.058994 & 0.015029 & -3.925298 & 0.0001 \\
\hline RES & 0.097960 & 0.025278 & 3.875379 & 0.0001 \\
\hline TAN & 0.185199 & 0.021708 & 8.531386 & 0.0000 \\
\hline R-squared & 0.759356 & \multicolumn{2}{|c|}{ Mean dependent var } & 0.805556 \\
\hline Adjusted R-squared & 0.755957 & \multicolumn{2}{|c|}{ S.D. dependent var } & 0.396323 \\
\hline S.E. of regression & 0.195786 & \multicolumn{2}{|c|}{ Akaike info criterion } & -0.407058 \\
\hline Sum squared resid & 13.56965 & \multicolumn{2}{|c|}{ Schwarz criterion } & -0.342290 \\
\hline Log likelihood & 79.27048 & \multicolumn{2}{|c|}{ Hannan-Quinn criter. } & -0.381305 \\
\hline F-statistic & 223.4106 & \multicolumn{2}{|c|}{ Durbin-Watson stat } & 0.131684 \\
\hline Prob(F-statistic) & 0.000000 & & & \\
\hline
\end{tabular}

\section{E-veiws 10 output}

This section present the result of the regression analysis and the test of hypothesis formulated. Assurance impacts ICT innovation about 0.313837, meaning that for every $1 \%$ increase in ICT innovation assurance increases at about $31 \%$. The coefficient of empathy was -0.22517 indicating that for any increase in ICT innovation leads to about $22 \%$ decrease in Empathy. Reliability had a coefficient of -0.058994 showing that for every increase in ICT innovation leads to a decrease in about $5.8 \%$ in reliability. While the Responsiveness coefficient is 0.097960 indicating that for any increase in ICT innovation, the level of responsiveness would be about $9.7 \%$. And the tangibility coefficient is 0.185199 , proofing that for any increase in ICT innovation, tangibility must have increase by $1.8 \%$.

The $\mathrm{R}^{2}$ is 0.759356 indicating that it is a good fit for the population sample taken. As the value of $\mathrm{R}^{2}$ ranges between 0 and 1 . With 1 indicating a perfect fit for the population. The $\mathrm{R}$ adjusted is 0.755957 which supports the $\mathrm{R}^{2}$ indicating that the sample size chosen is a good estimate of the population size. The standard error of all the independent variables are less than 0.05 (5\%). It implies that the standard errors are statistically significant. The Probability statistics are close to infinity indicating errors are minimal.

The DW statistics obtained was 0.131684 indicating minimal auto correlation as the test for 
Durbin Watson ranges between 2 and 4. However the problem of autocorrelation is common to time series data, and given our data, which are not time series, we accept stating our Dw is significant. Thus, the null hypothesis will be rejected and the alternative hypothesis that says there is significant impact of ICT innovation on service quality be accepted. The F- statistics is $223.41 \%$ which is high and signifies that the model is well fitted. The F-statistics is 0.0000 which is less than $5 \%$. This implies that all the variable combined together have an influence on ICT innovation, since the value of the F-statistics is less than 0.05 , the null hypothesis is rejected and alternative accepted.

\section{Appendix}

Table-1: Sample size frame

\begin{tabular}{|l|ll|l|l|c|}
\hline $\begin{array}{l}\text { Senatorial } \\
\text { District }\end{array}$ & \multicolumn{2}{|c|}{ LGCs } & $\begin{array}{l}\text { NPC } \\
\text { Figure }\end{array}$ & $\begin{array}{l}\text { Population } \\
\text { Account holder }\end{array}$ & No of Respondents \\
\hline Kaduna North & 1. & Zaria & 406,990 & 143228.13 & 53 \\
\hline & 2. Lere & 339,740 & 119561.47 & 44 \\
\hline & 3. & Sabon Gari & 291,358 & 102534.85 & 38 \\
\hline Kaduna Central & 1. Igabi & 430,753 & 151590.82 & 56 \\
\hline & 2. Kaduna south & 402,731 & 141729.30 & 52 \\
\hline & 3. Kaduna North & 364,575 & 128301.07 & 47 \\
\hline Kaduna South & 1. Zango & 318,991 & 112259.47 & 41 \\
\hline & 2. Jema'a & 278,202 & 97904.99 & 36 \\
\hline Total & 3. Kachia & 252,568 & 88883.86 & 33 \\
\hline
\end{tabular}

Source: Field Survey (2018) carried out by the researcher

\section{CONCLUSION AND RECOMMENDATIONS}

The study revealed how Service quality components namely, tangible, empathy, responsiveness, assurance and reliability impact on ICT innovation. The study revealed that customers do appreciate the physical attribute of the bank and should improve on some features of ICT product. Bank should respond more swiftly to customer's complaint and also ensure that there is cooperation image and credibility is not compromise. It also revealed the need for bank staff to at all time stick to promise made to customers. The management of the bank should ensure that those saddle with the responsibility of attending to customers are proactive and also have a defined time-bound on any issue brought by the customer. Staff development is key because they are the people that will produce goods of great value. The need to train staff locally and internationally is very important, this will help trigger the innovative traits in them.

The Banks should ensure that staff are aware and fully trained on use of ICT products. When staff are enlightened, they would educate customers on the uses and convenience of the physical facilities and ICT products that the bank possess. Bank management should design a format that will track how long it takes the back office staff to resolve complaints that emanates from e-banking transactions. This will make the lazy staff to sit up as this format will be used for yearly staff appraisal. Bank should ensure that they employ enough workers to carry out task, as most banks are understaff and this results in poor service delivery. When the bank is properly staffed, the time span for service delivery would be shorter, and thus the services become more efficient. Proper technicians that are trained to maintain the Atms and POS should be employed for the maintenance of the machines instead of just anybody as the banks do in a bid to cut cost. This could lead to more efficiency in the services provided using the POS and ATMs.

\section{REFERENCES}

1. Oluwagbemi, O., Abah, J., \& Achimugu, P. (2011). The impact of information technology in Nigeria's banking industry. Journal of Computer Science and Engineering, 7(2), 63-67.

2. Ugwu, A. P., \& Safari, M. (2016). The impact of information and communication technology service quality on customer satisfaction in the banking sector of Nigeria. Journal of Insurance and Financial Management, 1(1).

3. Nwokike, N. (2016). Invest in ICT Nigeria: A world of limitless possibilities.nwokike@ncc.gov.ng.

4. Adewoye, J. O. (2013). Impact of mobile banking on service delivery in the Nigerian commercial bank. Retrieved from http://www.irmbrjournal.com

5. Bichanga, W. O., \& Ali, Y. W. (2014). Effect of ebanking on growth of customer base in Kenyan banks. International Journal of Management Science and Information Technology, 11, 48-63.

6. Gvozdanovic, I., \& Solomon, O. M. (2016). The effect of electronic banking in financial supply chain: E-banking in Eritrea. Journal of Global Economic, 4(2), 17.

7. Fenuga, O. J., \& Oladejo, R. K. (2010). The effect of electronic payment on customer service delivery in Nigerian banks. International Journal of Economic Development Research and Investment, 1(1), 227 239. 
8. Kwashie, W. (2012). The impact of electronic banking service delivery to customers of Ghana commercial bank limited: A study of Ghana commercial bank. (Master's thesis). Institute of Distance Learning, Kwame Nkruma University of Science and Technology, Ghana.

9. Tafa, M. A. (2013). The impact of electronic banking on customer satisfaction in Ethiopian banking industry: The case of customers of Dashen and Wogagen banks in Gonder city. (Master's Thesis). Retrieved from http://ssm.com/abstract=2354281

10. Adeoye, B., \& Lawason, O. (2012). Customer satisfaction and its implications for bank performance in Nigeria. Retrieved from http:www.bjournal.co.uk/BJASS.aspx.

11. Edesiri, G., \& Promise, E. (2013). The problems and prospects of e-transaction: The Nigerian perspective. Journal of Research in International and Management, 3(1), 10-16.

12. Ojeka, S. A., \& Ikefan, O. A. (2011). Electric commerce, automation and online in Nigeria: Challenges and benefits. School of Doctoral Studies (European Union) Journal, 39-49.

13. Onyedimekwu, O., \& Oruan, M. K. (2013). Empirical evaluation of customers' use of electronic banking system in Nigeria. Africa Journal of Computing \& ICT, 6 (1), 7-19.

14. Worku, G., Tilahun, A., \& Tafa, M. (2016). The impact of electronic banking on customer's satisfaction in Ethiopian banking industry. Business Finance Affair, 5(1), 74.

15. Ugwu, A. P., \& Safari, M. (2016). The impact of information and communication technology service quality on customer satisfaction in the banking sector of Nigeria. Journal of Insurance \& Financial Management, 1(1), 38-53.

16. Jahanshani A. A., Hajizadeh, G. M. A., Mirdhamadi, S. A., Nawaser, K., \& Khakar, S. M. S. (2014). The Effect of customer service and product quality on customer satisfaction and loyalty. Retrieved from http://elibrary. Kiu.ac.ug: 8080/jspui/ handle/1/88.

17. Peyton, R. M., Pitts, S., \& Kamery, R. H. (2003). Consumer satisfaction/dissatisfaction (CS/D): A review of the literature prior to the 1990s. In Allied Academies International Conference. Academy of Organizational Culture, Communications and Conflict. Proceedings (Vol. 8, No. 2, p. 41). Jordan Whitney Enterprises, Inc.

18. Erjavec, A. (Ed.). (2015). Aesthetic revolutions and twentieth-century avant-garde movements. Duke University Press.

19. Zeithaml, V. A., Bitner, M. J., Gremler, D. D., \& Pandit, A. (2006). Services marketing: Integrating customer focus across the firm.
20. Simon, V. T., \& Thomas, A. S. R. (2016). Effect of electronic banking on customer satisfaction in selected commercial banks, Kenya. International Academic Journal of Human Resource and Business Administration, 2(2), 41-63.

21. Li, Y., \& Sui, M. (2011). Literature analysis of innovation diffusion. Technology and investment, 2(03), 155-162.

22. Gontur, S., Hassan, S., \& Arin, Y. (2017). Influence of information communication in building customer loyalty among deposit money banks in Jos metropolis, north central Nigeria. International Journal of Economic and Business Management, 3(7), 38-55.

23. Odusina, A.O., \& Onakoya, S.A. (2017). Electronic payment system and customers' retention in banks: Implications for entrepreneurial development in Nigeria. Global Journal of Management and Business Research Finance, 17(6), 9-14

24. Ameme, B., \& Wireko, J. (2016). Impact of technological innovations on customers in the banking industry in developing countries. The Business Management Review, 7(3), 388-397.

25. Taiwo, J. N. (2016). Effect of ICT on accounting information system and organisation performance: The application of information and communication technology on accounting information system. European Journal of Business and Social Science, 5(2), 1-15.

26. Ilo, J. V. C., Ani, W. C., \& Chioke, N. S. (2014). Impact of technological innovation on delivery of banking services in Nigeria. International Conference on Economic, Education and Humanities.

27. Alabar, T. T., \& Agema, R. J. (2014). Information and communication technology and customer satisfaction in the Nigerian banking industry. Journal of Advanced Management Science, 2(4), 333-337.

28. Ankrah, E. (2012). Technology and service quality in the banking industry in Ghana. Information and Knowledge Management, 2(8), 52-60.

29. Wanga, C., \& Schueth, S. (2018). Financial inclusion insights. Retrieved from http://search.yahoo.com/yhs/search?hspart=adk\&hs imo=yhs

30. Ugorji, L. N., Ewuim, N. C., Agu, E. R., Ogbu, U. C., \& Ogu, O. A. (2018). The Effect Of The Universal Basic Education On Rural Formal Education In Ohaozara, Onicha And Ivo Local Government Areas Of Ebonyi State. Journal of Good Governance and Sustainable Development in Africa (JGGSDA), 4(2). 